\title{
Chest Wall Hodgkin Lymphoma
}

National Cancer Institute

\section{Source}

National Cancer Institute. Chest Wall Hodgkin Lymphoma. NCI Thesaurus. Code C6723.

A Hodgkin lymphoma that affects the structures of the chest wall. 